\title{
New records of Leopardus guigna in its northern-most distribution in Chile: implications for conservation
}

\author{
Constanza Napolitano ${ }^{1,2^{*}+}$ (D), Cristian Larraguibel-González ${ }^{3 \dagger}$, Amancay A. Cepeda-Mercado ${ }^{4}$, Pablo Vial ${ }^{5}$ and \\ Jim Sanderson ${ }^{6,7}$
}

\begin{abstract}
We report new records of the wild felid Leopardus guigna in its northern-most distribution, in the southern Coquimbo and northern Valparaíso regions, in northern-central Chile. To our knowledge, these are the northernmost confirmed guigna records to date. We discuss implications for the conservation of these fragile populations in the face of different anthropic threats.
\end{abstract}

Keywords: Northern-most distribution, Coquimbo region, Guigna, Wildlife, Conservation, Anthropic threats

The guigna (Leopardus guigna) [24], the smallest felid in the Americas, also has a restricted distribution, being found primarily in central and southern Chile $\left(30^{\circ}-48^{\circ} \mathrm{S}\right)$, including the large island of Chiloe (off the coast of southern Chile), and marginally in adjoining areas of southwestern Argentina $\left(39^{\circ}-46^{\circ} \mathrm{S}\right.$ west of $\left.70^{\circ} \mathrm{W}\right)$ from sea level to $2500 \mathrm{~m}[17,26,27,33]$.

Two subspecies are recognized based on morphological and genetic data: L. guigna tigrillo (from $30^{\circ}-38^{\circ} \mathrm{S}$ in Chile) has a lighter coat color and larger body size, inhabiting Mediterranean matorral and sclerophyll woodlands and forests in northern-central and central Chile, and L. guigna guigna (from $38^{\circ}-48^{\circ}$ in Chile and $39^{\circ}-46^{\circ} \mathrm{S}$ in Argentina west of $70^{\circ} \mathrm{W}$ ) is darker and smaller, inhabiting more-dense Valdivian temperate rainforest and north Patagonian forest in southern and extreme southern Chile and the Andean Patagonian forest in southwestern Argentina [26, 27].

\footnotetext{
* Correspondence: constanza.napolitano@ulagos.cl

${ }^{+}$Constanza Napolitano and Cristian Larraguibel-González contributed equally to this work.

'Departamento de Ciencias Biológicas y Biodiversidad, Universidad de Los Lagos, Osorno, Chile

${ }^{2}$ Instituto de Ecología y Biodiversidad (IEB), Santiago, Chile

Full list of author information is available at the end of the article
}

Guignas are closely associated with native Mediterranean forests and temperate rainforests, vegetation cover being a key ecological requirement for the species [34]. Guignas can adapt to inhabiting fragmented humandominated landscapes, using small forest fragments and vegetation corridors within the agricultural matrix to move across the landscape [12]. Movements take place exclusively in vegetated depressions or corridors, some as small as $3 \mathrm{~m}$ wide and the species never uses or crosses grazed pasture with vegetation $<0.4 \mathrm{~m}$ high [33]. Guignas have also been reported in pine plantations with dense understory [1].

Because of their restricted distribution, guignas are particularly vulnerable to the loss of native forest [29], which is currently fragmenting its area of occupancy [1, $28,33]$. Given that a high proportion of geographic areas throughout guigna range are suffering from habitat loss and fragmentation [8], the species is classified as Vulnerable with a decreasing population trend on the IUCN Red List (A2abc; C2a(i), [27]). Guignas are classified as Vulnerable (northern subspecies, from $39^{\circ} \mathrm{S}$ to its northern range limit) and Near Threatened (southern subspecies, from $39^{\circ} \mathrm{S}$ to its southern range limit) on the Chilean Species Classification Regulation [23]. The current population size (total number of mature individuals) has been

(c) The Author(s). 2020 Open Access This article is licensed under a Creative Commons Attribution 4.0 International License, which permits use, sharing, adaptation, distribution and reproduction in any medium or format, as long as you give

appropriate credit to the original author(s) and the source, provide a link to the Creative Commons licence, and indicate if changes were made. The images or other third party material in this article are included in the article's Creative Commons licence, unless indicated otherwise in a credit line to the material. If material is not included in the article's Creative Commons licence and your intended use is not permitted by statutory regulation or exceeds the permitted use, you will need to obtain permission directly from the copyright holder. To view a copy of this licence, visit http://creativecommons.org/licenses/by/4.0/. 
estimated to be fewer than 10,000 individuals following a precautionary but realistic approach [27].

For the northern subspecies $L$. g. tigrillo, published records from the northern-most part of the geographic distribution are scarce, including only (from north to south): Catapilco $\left(32^{\circ} 34^{\prime} \mathrm{S} 71^{\circ} 17^{\prime} \mathrm{W}\right)$ [26], La Campana-

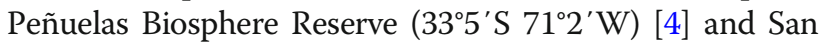
Antonio $\left(33^{\circ} 35^{\prime} \mathrm{S} 71^{\circ} 36^{\prime} \mathrm{W}\right)$ [26], all in Valparaiso region. To our knowledge, there are no published guigna records for the Coquimbo region, the northern-most area historically described as part of the species range [29]. Based on two confirmed records (specimens) from Valparaíso $\left(33^{\circ} \mathrm{S}\right)$ and Limache $\left(33^{\circ} \mathrm{S}\right)$ described by Osgood [30], Nowell \& Jackson [29] suggested $30^{\circ} \mathrm{S}$ latitude might be the northern-most limit of the guigna, probably as an extension of the sclerophyll forest and scrub habitat type distribution, and not based on any collected specimens or confirmed records in the region of Coquimbo.

We report new records of $L$. g. tigrillo in southern Coquimbo and northern Valparaíso regions, in northerncentral Chile, being these the northern-most confirmed records to date (Fig. 1). Records were obtained using trail cameras installed as part of different monitoring studies and opportunistically through photographic records during direct encounters, in years 2017, 2018 and 2020. Monitoring was conducted in the following sites: (1) One site in Cerro Palo Colorado (31 $59^{\prime} 50^{\prime \prime}$ S, 71 ${ }^{\circ} 27^{\prime} 46^{\prime \prime} \mathrm{W}$; Coquimbo region), sampling period from 6 August to 9 September 2018, using one trail camera (sampling effort 34 camera-

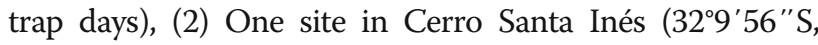
$71^{\circ} 29^{\prime} 41^{\prime \prime} \mathrm{W}$; Coquimbo region), first sampling period from 1 May to 31 October 2017, using one trail camera (sampling effort 180 camera-trap days) and second sampling period from 1 August to 30 November 2018 using one trail camera (sampling effort 120 camera-trap days), (3) One site in Quebrada Manantiales (32 $10^{\prime} 33^{\prime \prime} \mathrm{S}, 71^{\circ} 30^{\prime}$ 32 "W; Coquimbo region), sampling period from 1 February to 30 June 2017, using one trail camera (sampling effort 150 camera-trap days), and (4) One site in Bioparque Puquén (32 $13^{\prime} 34^{\prime \prime} \mathrm{S}, 71^{\circ} 31^{\prime} 0.1^{\prime \prime W}$; Valparaíso region), sampling period from 1 May to 30 June 2017, using one trail camera (sampling effort 60 camera-trap days).

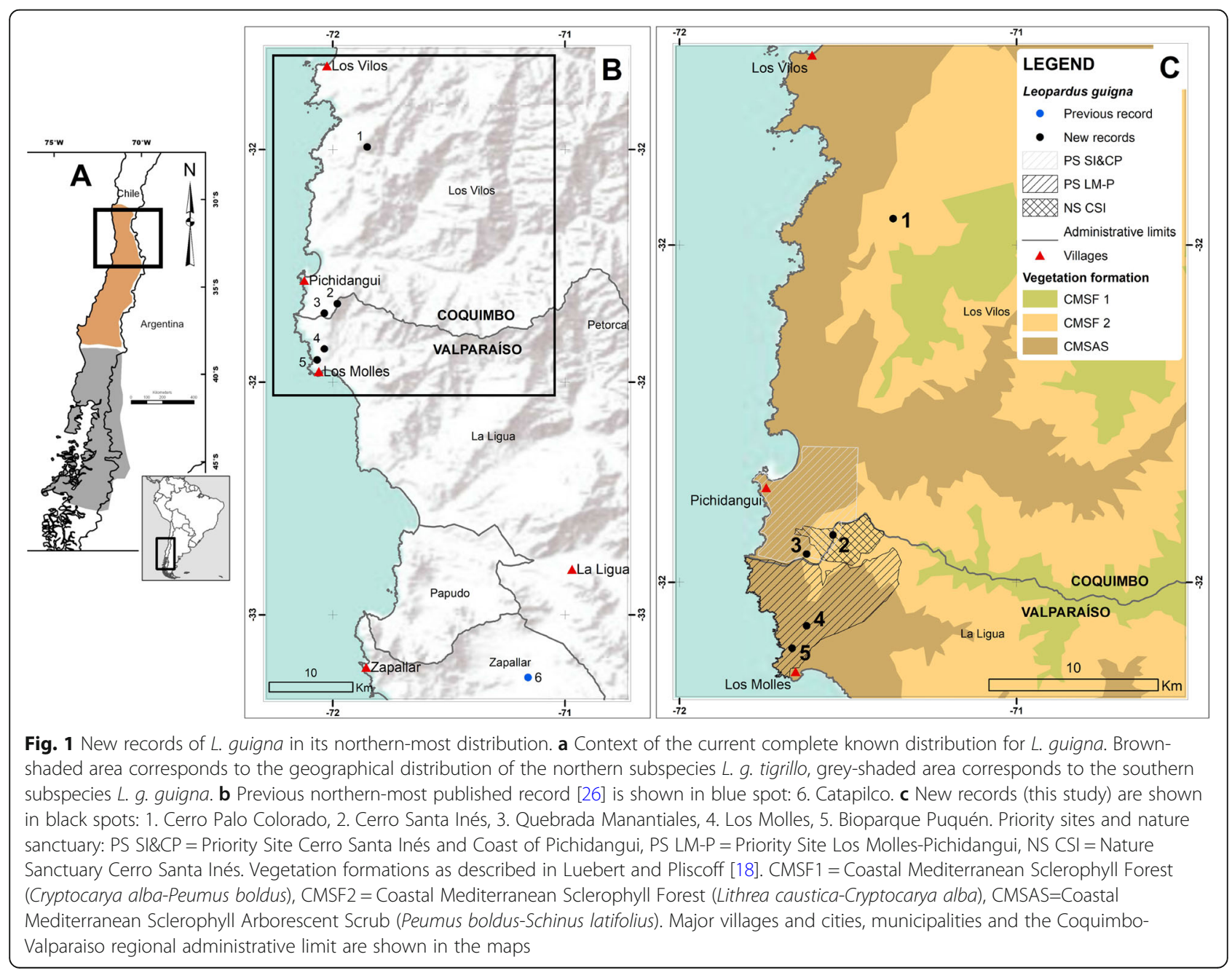


Cameras were baited with tuna, except for the Cerro Palo Colorado location which was not baited (Fig. 2).

We recorded guignas in 5 different sites: (i) Cerro Palo Colorado, one trail camera record (2.9\% capture success), (ii) Cerro Santa Inés, first sampling period: two trail camera records (1.1\% capture success), second sampling period: 5 trail camera records (4.2\% capture success), (iii) Quebrada Manantiales, 7 trail camera records (4.7\% capture success), (iv) Los Molles (32 $12^{\prime} 51^{\prime \prime} \mathrm{S}, 71^{\circ} 30^{\prime} 32^{\prime \prime} \mathrm{W}$; Valparaíso region), 1 direct encounter photographic record (15 March 2020), (v) Bioparque Puquén, 18 trail camera records (30\% capture success) (Figs. 1, 2). Records in each site were at least $60 \mathrm{~min}$ apart, thus considered independent events.

Our records add to previous reports in the northern Valparaíso region $[4,26]$, extending the northern range of L. g. tigrillo by approximately $66 \mathrm{~km}$ (lineal distance from Catapilco to Cerro Palo Colorado) and confirming its current presence in the region of Coquimbo.

Records from the Coastal mountain range (Cerro Palo Colorado, $473 \mathrm{~m}$ above sea level (masl)) were obtained in native forest with dense understory, near a natural spring pond. Records from Cerro Santa Inés were obtained in sclerophyll scrub immediately outside the cloud forest formation (560 masl). Both areas have been proposed as Priority Conservation Sites for threatened native flora and fauna $[5,36]$. These sites are located in a forested Coastal mountain range that extends from Cerro Santa Inés northwards to Quilimarí and Huentelauquén almost continuously for ca. $60 \mathrm{~km}$, reaching approximately 600 masl. A mosaic of small, isolated temperate rainforest remnant patches, dominated by the endemic tree Aextoxicon punctatum (olivillo), persist only on these coastal mountaintops (450-600 m) surrounded by a matrix of xerophytic vegetation receiving only sporadic rainfall [37]. These evergreen olivillo forests are distributed along the ocean-facing slopes and deep ravines of the Coastal mountain range north of $33^{\circ} \mathrm{S}$, persisting as a result of fogwater inputs [7]. These unique and highly diverse cloud forest patches harbor a rich floristic assemblage, closely related to Austral temperate rainforests [7], including other species such as Myrceugenia correifolia (petrillo), Lomatia dentata (avellanillo) and Citronella mucronata (naranjillo) [9]. Privately owned, this Coastal mountain range has neither a conservation plan in place nor protection under any conservation category. The range has small private conservation initiatives such as Cerro Santa Inés being recently declared a Nature Sanctuary (administered by the mining company Los Pelambres).

Records from the ravine Quebrada Manantiales (168 masl) along with records from Los Molles (110 masl) and Bioparque Puquén (38 masl) were obtained in areas of native coastal sclerophyll scrub habitat within a coastal fringe that extends between Los Molles and Pichidangui. Although privately owned, this area has been declared a Priority Conservation Site for the protection of flora and fauna species with high endemism, with several of them classified as Endangered [6]. This high conservation priority coastal fringe has neither a conservation plan in place nor protection under any conservation category, only small private initiatives such

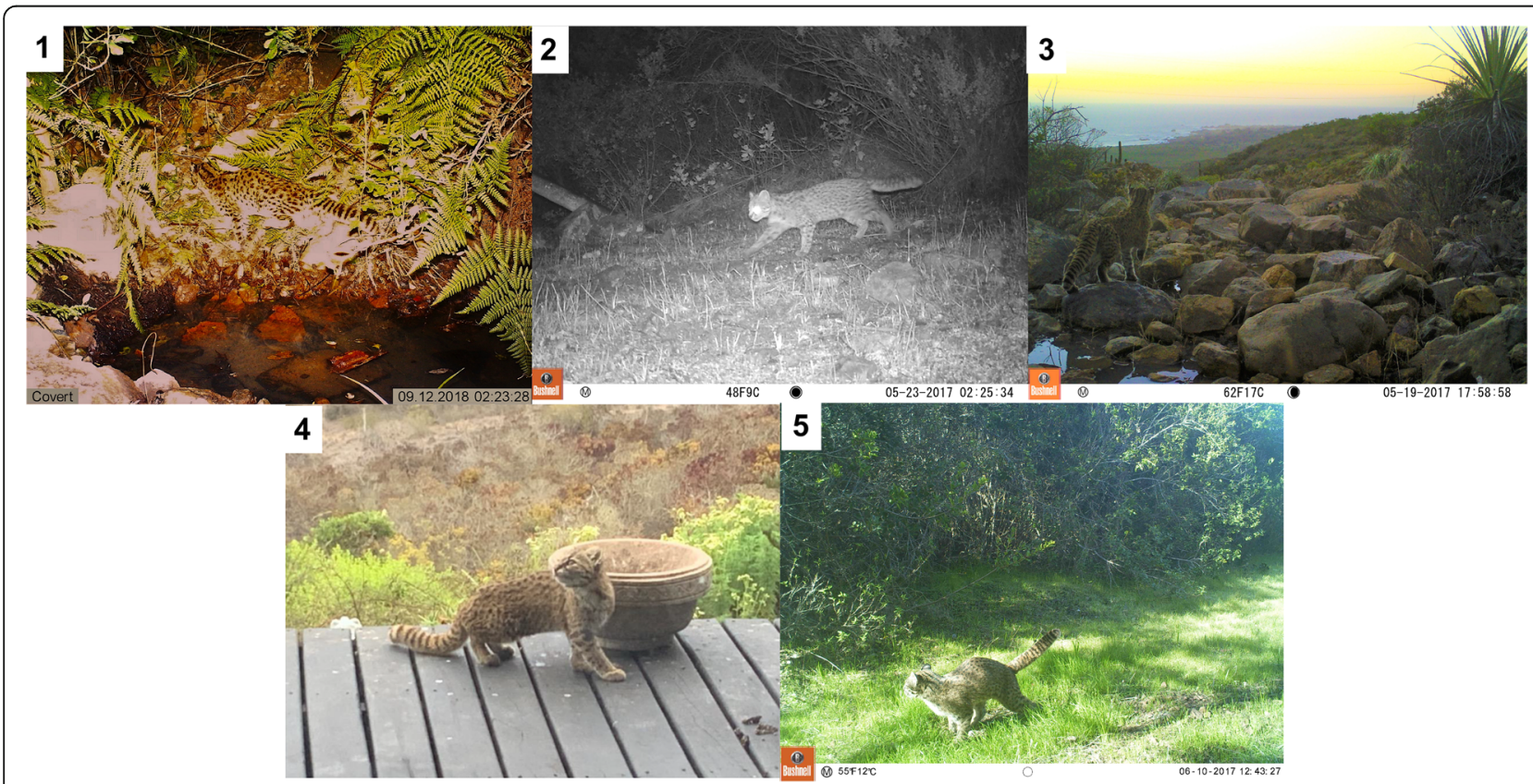

Fig. 2 New photographic records of L. guigna in its northern-most distribution. Trail camera pictures: (1) Cerro Palo Colorado, (2) Cerro Santa Inés, (3) Quebrada Manantiales, (5) Bioparque Puquén. Direct encounter photograph: (4) Los Molles. Location numbers as shown in Fig. 1 
as the natural conservation area Bioparque Puquén, located near Los Molles.

This ecosystem has been characterized as having high global value. The Chilean Winter Rainfall-Valdivian Forests biodiversity hotspot $\left(25-47^{\circ} \mathrm{S}\right)$ has been proposed as a critical ecosystem of high conservation priority due to its high endemism and for being under significant threat from human activities [3]. The sclerophyll forests and scrub vegetation type in Coquimbo region are the most septentrional of its distribution [11], coinciding with the northern-most limit of the guigna's range, in line with the species' key ecological requirement of vegetation cover. All the new records presented here are seemingly part of a large biological corridor (i.e., continuous, narrow patches of vegetation that facilitate movement among habitat patches) [6], probably connecting guigna populations across the landscape at a local scale.

Nevertheless, these areas are not free of anthropogenic pressure and threats consisting mainly of the conversion of native forest and scrub to crop plantations (primarily avocado and vine), rural real estate development, desertification and fires [2, 10, 21, 22]. Land subdivision has been identified as an ongoing threat for local wildlife such as the guigna [13]. Humans often inhabit rural lands with their domestic pets (dogs and cats). The minimum legal subdivision for rural lands in Chile is 0.5 ha $[19,20]$, which is far below home ranges described for free-roaming domestic cat (Felis catus) and dog (Canis familiaris) in rural landscapes [16, 35]. Irresponsible pet ownership, lack of movement restriction and poor health management of domestic pets increases the risk of disease transmission to guignas (and other native carnivores) [25, 32]. Free-roaming dogs also attack and kill guignas and other native mammals [31]. The guigna and other native species (e.g. culpeo fox Lycalopex culpaeus, pampas cat Leopardus colocola, lesser grison Galictis cuja and cururo Spalacopus cyanus) coexist in a highly modified habitat in contact with humans in areas such as Bioparque Puquén, constantly visited by tourists, or Los Molles, where countryside houses have flourished.

The current presence of guigna in these conservation strongholds is crucial. Special conservation strategies for populations of $L$. g. tigrillo in the northern edge of its distribution have been suggested by Napolitano et al. [26], who described them as quite isolated genetically from other groups across the species distribution and harboring unique genetic haplotypes. This population also harbors unique ecological adaptations to inhabit the dry Chilean Matorral ecosystem, so different from the Valdivian temperate rainforests in southern Chile that the southern subspecies L. g. guigna inhabits.

Moreover, populations inhabiting edges of geographical distributions have higher ecological fragility. Species' range limits are based on the assumption that environments deteriorate towards and beyond the range boundary, becoming less suitable for the species. That, in turn, leads to the species becoming less common towards the edges, with low population growth, small population size and a high extinction rate [14]. Edge populations are peripheral sinks that persist at the range edge only because of colonization from more abundant central source habitat populations (where environmental conditions for the species are most ideal) [15]. In a metapopulation approach, range edge populations occupy discrete patches that become increasingly less frequent [15]. Therefore, for these northern-most guigna populations we expect small population sizes and high overall extinction rates.

In sum, several human threats impacting the genetically unique northern-most guigna populations warrant the urgent need for more research, community-based conservation and protection of this ecoregion with high ecological value - the fragile and rich Chilean Matorral ecosystem.

\section{Acknowledgements \\ We specially thank Isol Liu for kindly donating her record of direct encounter. We thank Nicolás Gálvez and Eduardo Silva-Rodríguez who kindly agreed to peer-review our pictures. We are grateful to Mena Grossmann who kindly proofread the manuscript. Acknowledgements to Proyecto Diagnóstico de Sitios de Alto Valor para la Conservación en la Región de Valparaíso, Fase II, Línea 3. Código BIP N 30137941-0, funded by the Valparaíso regional government.}

\section{Authors' contributions}

CN conceived the study. CL, AACM, PV participated in fieldwork and coordinated surveys. CL, PV set and operated the cameras. CN, CL, AACM, PV, JS identified the records. AACM created the maps. CN, CL, JS wrote the manuscript. All authors read and approved the final manuscript.

Funding

ANID PAI 77190064 (CN).

Availability of data and materials

The datasets used and/or analyzed during the current study are available from the corresponding author on reasonable request.

Ethics approval and consent to participate Not applicable.

Consent for publication

Not applicable.

Competing interests

The authors declared that they have no competing interests.

Author details

'Departamento de Ciencias Biológicas y Biodiversidad, Universidad de Los Lagos, Osorno, Chile. ${ }^{2}$ Instituto de Ecología y Biodiversidad (IEB), Santiago, Chile. ${ }^{3}$ Instituto de Geografía, Pontifica Universidad Católica de Valparaíso, Valparaíso, Chile. ${ }^{4}$ Fundación Irimi, Copiapó, Chile. ${ }^{5}$ Fundación Abejas de Chile, Santiago, Chile. ${ }^{6}$ Global Wildlife Conservation (GWC), Austin, TX, USA. ${ }^{7}$ Small Wild Cat Conservation Foundation, Corrales, NM, USA. 
Received: 4 July 2020 Accepted: 3 September 2020

Published online: 29 September 2020

\section{References}

1. Acosta-Jamett G, Simonetti JA. Habitat use by Oncifelis guigna and Pseudalopex culpaeus in a fragmented forest landscape in Central Chile. Biodivers Conserv. 2004;13:1135-51.

2. Armesto JJ, Arroyo MTK, Hinojosa LF. The mediterranean environment of Central Chile. In: Veblen TT, Young KR, Orme AR, editors. The physical geography of South America. Oxford: University Press; 2007. p. 184-99.

3. Arroyo MTK, Marquet PA, Marticorena C, Simonetti JA, Cavieres L, Squeo F, Rozzi TR. Chilean winter rainfall-Valdivian forests. In: Mittermeier RA, Gil PR, Hoffmann M, Pilgrim J, Brooks T, Mittermeier CG, Lamoreux J, da Fonseca $\mathrm{GAB}$, editors. Hotspots revisited: Earth's biologically wealthiest and most threatened ecosystems. México D.F: CEMEX; 2004. p. 99-103.

4. Beltrami E, Osorio Popiolek CT, Bonacic C. Foxes and small wild felids cooccur spatially with domestic dogs in a highly disturbed landscape in the Mediterranean ecosystem of Central Chile. Zagreb: Conference UFAW International Animal Welfare Science Symposium; 2015

5. Comisión Nacional del Medio Ambiente. Estrategia y Plan de Acción para la Conservación de la Diversidad Biológica región de Valparaíso. Santiago: CONAMA-PNUD; 2005

6. Comisión Nacional del Medio Ambiente. Información Ambiental Sitio Prioritario de Biodiversidad Los Molles-Pichidangui. Región de Valparaíso. Valparaíso: Informe Ingienería Ambiental \& Biotecnología; 2007.

7. Del-Val E, Armesto JJ, Barbosa O, Christie DA, Gutiérrez AG, Jones CG, Marquet PA, Weathers KC. Rain Forest Islands in the Chilean semiarid region: fog-dependency, ecosystem persistence and tree regeneration. Ecosystems. 2006;9:598

8. Echeverria C, Coomes D, Salas J, Rey-Benayas JM, Lara A, Newton A. Rapid deforestation and fragmentation of Chilean temperate forests. Biol Conserv. 2006;130:481-94

9. Francois JP. Eslabones de una cadena rota: el caso del bosque relicto de Santa Inés. In: Squeo FA, Gutiérrez JR, Hernández IR, editors. Historia Natural del Parque Nacional Bosque Fray Jorge. La Serena: Ediciones Universidad de La Serena; 2004. p. 205-18.

10. Flores-Villanelo JP, Carmona López M, Rojas SJ. Estado actual de los suelos de la Región de Coquimbo. Uso y Degradación. Propuesta de implementación, capacitación y actualización de sistemas de información comunal para la toma de decisiones (SIG) en la Región de Coquimbo. Coquimbo: CIREN-Ministerio de Agricultura-Gobierno Regional de Coquimbo; 2012.

11. Gajardo R. La Vegetación Natural de Chile; Clasificación y Distribución Geográfica. Santiago: Editorial Universitaria; 1994.

12. Gálvez N, Hernández F, Laker J, Gilabert H, Petitpas R, Bonacic C, Gimona A, Hester A, MacDonald D. Forest cover outside protected areas plays an important role in the conservation of the vulnerable guiña Leopardus guigna. Oryx. 2013;47:251-8.

13. Gálvez N, Guillera-Arroita G, St John FA, Schüttler E, MacDonald DW, Davies ZG. A spatially integrated framework for assessing socioecological drivers of carnivore decline. J Appl Ecol. 2018;55:1393-405.

14. Geber MA. To the edge: studies of Species' range limits. New Phytol. 2008; 178:228-30.

15. Kanda LL, Fuller TK, Sievert PR, Kellogg RL. Seasonal source-sink dynamics at the edge of a species' range. Ecology. 2009;90:1574-85.

16. López-Jara MJ, Sacristán I, Acuña F, Aguilar E, García S, Marón F, Contreras P, Silva-Rodríguez EA, Napolitano C. Free-roaming domestic cats near conservation areas in Chile: Spatial movements, human care and risks for wildlife. n.d. In revision. Unpublished data.

17. Lucherini M, Merino MJ, Soler L. First data on the kodkod in Argentina. Cat News. 2000;32:19-20.

18. Luebert F, Pliscoff P. Sinopsis bioclimática y vegetacional de Chile. Santiago: Editorial Universitaria; 2018.

19. Márquez M. El ordenamiento territorial de los espacios rurales en Chile. Rev Geogr Norte Gd. 1999;26:113-8.

20. Ministerio de Vivienda y Urbanismo. Ordenanza General de Urbanismo y Construcciones. Santiago: Ministerio de Vivienda y Urbanismo; 1992.

21. Ministerio del Medio Ambiente. Diagnóstico del estado y tendencias de la biodiversidad. Región de Valparaíso. Santiago: Ministerio del Medio Ambiente-PNUD; 2016
22. Ministerio del Medio Ambiente. Diagnóstico del estado y tendencias de la biodiversidad. Región de Coquimbo. Santiago: Ministerio del Medio Ambiente-PNUD; 2016.

23. Ministerio del Medio Ambiente. Decreto Supremo 42. Séptimo proceso Clasificación de Especies según su Estado de Conservación. Santiago: Ministerio del Medio Ambiente; 2011.

24. Molina Jl. Saggio sulla storia naturale de Chili. Boloña: Stamperia di S. Tomaso d'Aquino; 1782. Available in Biblioteca Digital - Real Jardín Botánico - CSIC.

25. Mora M, Napolitano C, Ortega R, Poulin E, Pizarro J. Feline immunodeficiency virus and feline leukemia virus infection in free-ranging guignas (Leopardus guigna) and sympatric domestic cats in human perturbed landscapes on Chiloé Island, Chile. J Wildl Dis. 2015;51:199-208.

26. Napolitano C, Sanderson J, Bennett M, Johnson WE, Hoelzel R, Dunstone N, Freer R, Ritland K, Poulin E. Phylogeography and population history of Leopardus guigna, the smallest American felid. Conserv Genet. 2014;15:63153.

27. Napolitano C, Gálvez N, Bennett M, Acosta-Jamett G, Sanderson J. Leopardus guigna. In: The IUCN red list of threatened species 2015: e. T15311A50657245; 2015.

28. Napolitano C, Díaz D, Sanderson J, Johnson WE, Ritland K, Ritland CE, Poulin E. Reduced genetic diversity and increased dispersal in Guigna (Leopardus guigna) in Chilean fragmented landscapes. J Hered. 2015;106:522-36.

29. Nowell K, Jackson P. Status survey and conservation action plan: wild cats. Gland: IUCN/SSC cat specialist. Group. 1996.

30. Osgood WH. The mammals of Chile. Field Mus Nat Hist. 1943;30:1-268.

31. Romero F, Espinoza A, Sallaberry-Pincheira N, Napolitano C. A five-year retrospective study on patterns of casuistry and insights on the current status of wildlife rescue and rehabilitation centers in Chile. Rev Chil Hist Nat. 2019:92:6.

32. Sacristán I, Esperon F, Pérez R, Acuña F, Aguilar E, Garcia S, López MJ, Neves E, Cabello J, Hidalgo-Hermoso E, Terio KA, Millán J, Poulin E, Napolitano C. Epidemiology, molecular characterization and risk factors of Carnivore protoparvovirus-1 infection and disease in the wild felid Leopardus guigna in Chile. 2020. https://doi.org/10.22541/au.159250158.83984172.

33. Sanderson JG, Sunquist ME, Iriarte AW. Natural history and landscape-use of guignas (Oncifelis guigna) on Isla Grande de Chloe, Chile. J Mammal. 2002; 83:608.

34. Schüttler E, Klenke R, Galuppo S, Castro RA, Bonacic C, Laker J, Henle K. Habitat use and sensitivity to fragmentation in America's smallest wildcat. Mamm Biol. 2017:86:1-8

35. Sepúlveda M, Pelican K, Cross P, Eguren A, Singer R. Fine-scale movements of rural free-ranging dogs in conservation areas in the temperate rainforest of the coastal range of southern Chile. Mamm Biol. 2015;80:290-7.

36. Squeo FA, Arancio G, Cavieres LA. Sitios Prioritarios para la Conservación de la Flora Nativa con Riesgos de Extinción en la IV Región de Coquimbo, Chile. In: Squeo FA, Arancio G, Gutiérrez JR, editors. Libro Rojo de la Flora Nativa y de los Sitios Prioritarios para su Conservación: Región de Coquimbo. La Serena: Ediciones Universidad de La Serena; 2001. p. 171-93.

37. Squeo FA, Arancio G, Novoa-Jerez J. Heterogeneidad y diversidad florística del Bosque de Fray Jorge. In: Squeo FA, Gutiérrez JR, Hernández IR, editors. Historia natural del Parque Nacional Bosque Fray Jorge. La Serena: Ediciones Universidad de La Serena; 2004. p. 173-85.

\section{Publisher's Note}

Springer Nature remains neutral with regard to jurisdictional claims in published maps and institutional affiliations.

\section{Ready to submit your research? Choose BMC and benefit from}

- fast, convenient online submission

- thorough peer review by experienced researchers in your field

- rapid publication on acceptance

- support for research data, including large and complex data types

- gold Open Access which fosters wider collaboration and increased citations

- maximum visibility for your research: over $100 \mathrm{M}$ website views per year

At $\mathrm{BMC}$, research is always in progress.

Learn more biomedcentral.com/submission 